\title{
Cold stress alters transcription in meiotic anthers of cold tolerant chickpea (Cicer arietinum L.)
}

\author{
Kamal Dev Sharma ${ }^{1 *}$ and Harsh Nayyar ${ }^{2}$
}

\begin{abstract}
Background: Cold stress at reproductive phase in susceptible chickpea (Cicer arietinum L.) leads to pollen sterility induced flower abortion. The tolerant genotypes, on the other hand, produce viable pollen and set seed under cold stress. Genomic information on pollen development in cold-tolerant chickpea under cold stress is currently unavailable.

Results: DDRT-PCR analysis was carried out to identify anther genes involved in cold tolerance in chickpea genotype ICC16349 (cold-tolerant). A total of 9205 EST bands were analyzed. Cold stress altered expression of 127 ESTs (90 up-regulated, 37 down-regulated) in anthers, more than two third (92) of which were novel with unknown protein identity and function. Remaining about one third (35) belonged to several functional categories such as pollen development, signal transduction, ion transport, transcription, carbohydrate metabolism, translation, energy and cell division. The categories with more number of transcripts were carbohydrate/triacylglycerol metabolism, signal transduction, pollen development and transport. All but two transcripts in these categories were up-regulated under cold stress. To identify time of regulation after stress and organ specificity, expression levels of 25 differentially regulated transcripts were also studied in anthers at six time points and in four organs (anthers, gynoecium, leaves and roots) at four time points.

Conclusions: Limited number of genes were involved in regulating cold tolerance in chickpea anthers. Moreover, the cold tolerance was manifested by up-regulation of majority of the differentially expressed transcripts. The anthers appeared to employ dual cold tolerance mechanism based on their protection from cold by enhancing triacylglycerol and carbohydrate metabolism; and maintenance of normal pollen development by regulating pollen development genes. Functional characterization of about two third of the novel genes is needed to have precise understanding of the cold tolerance mechanisms in chickpea anthers.
\end{abstract}

Keywords: Anthers, Cicer arietinum, Cold stress, Cold tolerance, Gene expression, Male gametophyte, Pollen

\section{Background}

Male gametophyte in flowering plants is a highly dynamic structure with active growth and high metabolic activity. It is an organ with highest sink strength in the flower and large amounts of sugars are transported to anthers to support its development and formation of pollen grains [1]. Anther is also the organ with high sensitivity to cold stress [2]. Within anther, the pollen development and pollen function under stress is the weakest link in plant sexual reproduction [3]. Pollen development proceeds through meiosis and sensitivity of the male gametophyte to stresses increases considerably after

\footnotetext{
*Correspondence: kml1967@rediffmail.com

'Department of Agricultural Biotechnology, CSK HP Agricultural University, Palampur 176062, HP, India

Full list of author information is available at the end of the article
}

the onset of meiosis [4]. Pollen maturation is also one of the most sensitive stages [5]. Nutrition to young microspores and developing pollen grains is provided by the tapetum, which functions at maximum capacity to synthesize locular fluid [6]. At the same time, the pollen wall is also deposited on the developing pollen [6,7]. Abiotic stress at the time of tapetum development aborts male gamete formation and results in sterile pollen $[3,8]$. Cold stress perturb carbohydrate metabolism and alters anther morphology $[8,9]$. As a whole, the temperature stress reduces pollen development, pollen fertility, anthesis, pollination and pollen tube growth $[4,10]$.

Chickpea (Cicer arietinum L.), a leguminous annual flowering herb, is grown for its protein rich grains in several parts of the world. The crop is a native of tropical Mediterranean region and is sensitive to chilling 
temperatures [11]. Temperatures below $15^{\circ} \mathrm{C}$ abort chickpea flowers and decrease the number of pods per plant and seeds per pod [9,12-16]. Chilling stress prevailing during flowering and grain filling leads to nutritional deficiencies in the tapetum [13]. The susceptible genotypes show reduction in anther dehiscence, pollen load on the stigma, pollen germination and pollen tube growth $[9,17]$. Growing tips of the pollen tubes also show distortions $[9,17]$ and fertilization is poor. Cold sensitivity in susceptible genotypes is manifested by increase in oxidative stress, increase in membrane damage, decrease in chlorophyll and relative leaf water content [15]. Flower abortion due to cold stress in chickpea is associated with lower levels of sucrose, glucose and fructose in anthers and pollen [13]. Of late, chickpea genotypes, ICC16348 and ICC16349, were found to be tolerant to cold [15]. These genotypes developed flowers and set pods at low temperatures. Cold tolerance in ICC16349 was manifested in the form of low electrolyte leakage and high chlorophyll and water content [15]. Total sugars and starch were found to be higher in cold tolerant genotypes compared to the susceptible ones whereas oxidative stress was low [15].

There is however, no study on identification or isolation of male or female gametophyte genes involved in reproduction or those involved in stress tolerance/susceptibility. Some transcriptomics studies on stress biology in chickpea organs other than anthers and gynoecium have been conducted [18-23]. The present study identified anther genes regulated differentially in response to cold stress in a cold-tolerant genotype. In addition, spatial and temporal expressions of selected genes in anthers, gynoecium, leaves and roots were also studied with the aim to identify organ specificity in gene expression under cold and to get an insight of gene regulation in different organs. To our knowledge, this is the first study on transcriptome of anthers in chickpea and other field legumes under cold stress conditions.

\section{Results}

\section{Genome-wide expression analysis}

To identify chickpea male gametophyte genes regulated differentially under cold stress, anther transcriptome of a cold-tolerant genotype (ICC16349) at $72 \mathrm{~h}$ post cold stress was compared with the transcriptome of anthers of plants growing under normal conditions (see Figure 1 for outline of the experimental procedure). Our previous studies have already established that ICC16349 possessed high degree of tolerance to cold and could flower and set seed under low temperature conditions [15]. DDRT-PCR generated a total of 10,567 bands. Bands smaller than 75 bases (1362 nos.) were rejected and remaining 9205 EST bands were analyzed. Of these 9205 EST bands, 206 were differentially regulated with more than two fold change in anthers of cold stressed plants. Among the differentially

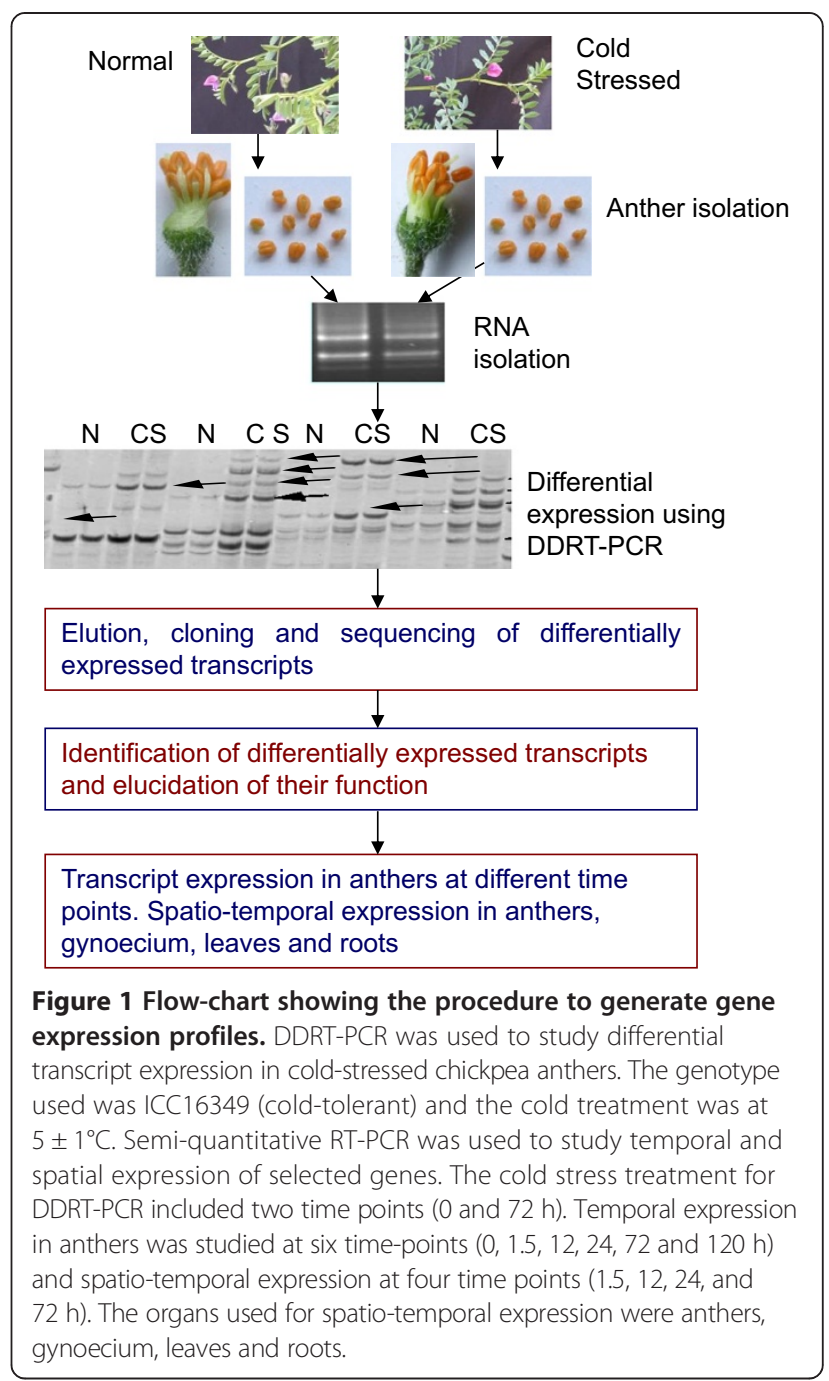

regulated bands, 133 were up-regulated (UP) and 73 down-regulated (DR). Sequence editing, clustering and contig analysis revealed that expression of only 127 ESTs [90 (70.9\%) UP; 37 (29.1\%) DR was altered due to cold stress. The proportion of UP genes compared to DR ones was 2.4 indicating that cold-tolerance in anthers of ICC16349 was manifested primarily by the enhanced expression of genes.

\section{Functional analysis of differentially expressed genes}

Information on identity, cellular component, biological and molecular functions of all the genes was obtained form NCBI-BLAST, Gene Ontology (GO) analysis and KEGG pathway (Additional file 1). Based on GO analysis, the genes were classified into three main GO categories, the biological process (BP), cellular component (CC) and molecular function (MF). Of the 127 genes, only 35 (27.5\%, 28 UP, 7 DR) could be functionally characterized according to GO descriptions (Table 1). The remaining 92 ESTs (more than two third) were of unknown MF and BP 
Table 1 Gene ontology score-based categorization of differentially regulated transcripts in anthers of ICC16349

\begin{tabular}{llll}
\hline & Up-regulated & Down-regulated & Total \\
\hline Total & 90 & 37 & 127 \\
BP & 25 & 6 & 31 \\
CC & 16 & 5 & 21 \\
MF & 26 & 5 & 31 \\
\hline
\end{tabular}

$\mathrm{BP}$, biological process; CC, cellular component; MF, molecular function.

(Additional file 1). The ESTs with altered expression were further assigned into $10 \mathrm{GO}$ subcategories (Figure 2, Table 2). Among these 10 subcategories, those related to ion transport, pollen development, signal transduction and carbohydrate metabolism appeared to be more important for cold tolerance because the number of altered transcripts in these subcategories were more. Twenty five of the functionally characterized transcripts $(71.4 \%$ of transcripts with GO description) belonged to these four subcategories. Besides more number of genes, other unique feature was up-regulation of majority of the transcripts (23 out of $25,92 \%$ ) in these subcategories. Only two genes in these subcategories were repressed, one each for ion transport and pollen development. The GO subcategories with relatively less number of genes were translation, transcription, energy, cell division and metabolic processes. The genes in these subcategories did not show a definite trend as some of those were UP whereas others were DR.

The subcategory pollen development had maximum number (ten) of altered transcripts. Seven of these are listed under subcategory pollen, one (beta-galactosidase) under carbohydrate metabolism and two (cysteine-rich receptor-like protein kinase and $\mathrm{CDC} 2 \mathrm{C}$ ) under signal transduction (Table 2). As per GO and available literature, the $\mathrm{BP}$ of these genes were tetrad separation and pollen release [pectin methylesterase (PME), pectin esterase (PE)], pollen development [SNAP receptor, protein WAX2, early nodulin-like protein (ENODL6), beta-galactosidase] and pollen tube growth (peroxisomal $\mathrm{ABC}$ transporter, PME and PE). The MF of pollen specific transcripts were signal transduction, transcription, cell wall modification, protein transport, fatty acid transport and ion binding (Table 2). Except one gene (ENODL6), all genes in this subcategory were UP. Carbohydrates are considered vital for normal pollen development and four carbohydrate metabolism genes i.e. beta-galactosidase, glycerol kinase, aconitate hydratase and sucrose phosphorylase were up-regulated (Table 2). The function of these genes is to release free sugars from complex carbohydrates or triacyglycerol (glycerol kinase).

Additional information on differentially-regulated genes was also obtained from NCBI-BLAST (Additional file 1). Of the 127 differentially regulated chickpea ESTs identified in the present study, only 40 had similarity to chickpea ESTs listed in the databases (EST database, http://www. ncbi.nlm.nih.gov/nucest?term=chickpea). The remaining 87 ESTs were new records for chickpea. Large proportion of new ESTs identified in the present study might be attributed to the source organ used i.e. anther. This is the first study on chickpea anther transcriptome. In earlier studies, the leaf, stem and bud transcriptomes were analyzed [18-23]. The analysis revealed that 18 of the 40 ESTs were common between cold and drought, 6 between cold and salinity, 3 between cold and biotic stresses, and 5 among cold, drought and salinity (Figure 3). Four of the ESTs were common to all the four stresses i.e. cold, drought, salinity and biotic.

\section{Transcript expression at different time points in chickpea anthers}

To confirm the DDRT-PCR expression profile and to study gene regulation at the beginning of cold stress and at various time points thereafter, reverse transcription quantitative polymerase chain reaction (RT-qPCR) analysis of anthers of the cold-tolerant genotype was carried out at six time points $(0 \mathrm{~h}, 1.5 \mathrm{~h}, 12 \mathrm{~h}, 24 \mathrm{~h}, 72 \mathrm{~h}$ and $120 \mathrm{~h})$ after cold stress. A representative set of 25 ESTs belonging to $9 \mathrm{GO}$ categories (signal transduction, transcription, carbohydrate metabolism, pollen development, transport, defense, translation, cell division and unknown function)

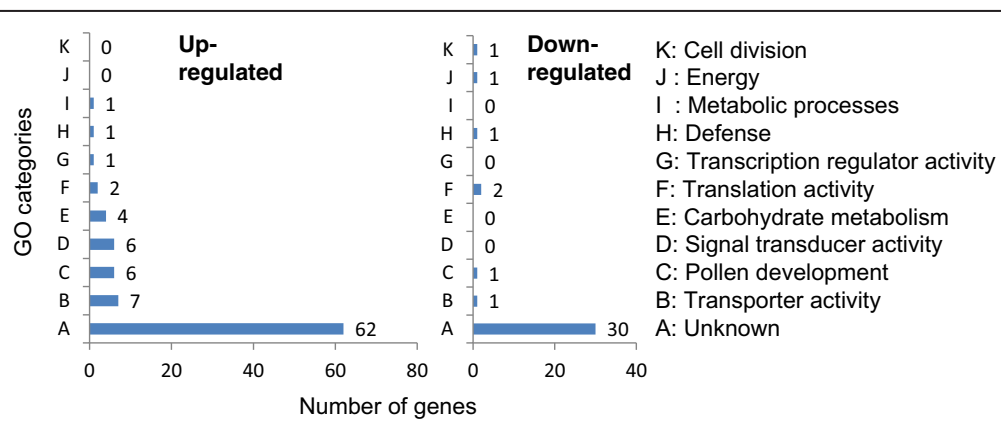

Figure 2 Functional categorization of cold responsive anther genes in ICC16349. The number of genes were finalized using the filtering criteria of fold change $>2.0$ and P-value correction $\leq 0.05$ by FDR (Benjamini-Hochberg). Genes were classified into 11 different functional categories based on gene ontology. Number of genes in each category are presented at the termini of bars. 
Table 2 Functional characterization of 35 differentially expressed transcripts from the DDRT-PCR

\begin{tabular}{|c|c|c|c|c|}
\hline Transcript no & Homology and e-value & Biological function & Molecular function & $\begin{array}{l}\text { Cellular } \\
\text { component }\end{array}$ \\
\hline \multicolumn{5}{|c|}{ Transporter activity genes } \\
\hline$A 3^{*}$ & $\begin{array}{l}\text { Cation/ } / \mathrm{H}^{+} \text {antiporter 14, Arabidopsis } \\
\text { thaliana, AT1G06970, 4.1e-05 }\end{array}$ & Ion transport & Antiporter activity & Membrane \\
\hline $\mathrm{A} 20^{*}$ & $\begin{array}{l}\text { Cation efflux system protein, Agrobacterium } \\
\text { radiobactor K84, YP_002543585.1, } 0.33\end{array}$ & $\begin{array}{l}\text { lon transport, transmembrane } \\
\text { transport }\end{array}$ & Copper ion binding & Membrane \\
\hline A82-1* & $\begin{array}{l}\text { Heavy metal efflux pump CzCA, Gamma } \\
\text { proteobacterium, ZP_05061697.1, 4e-03 }\end{array}$ & Unknown & $\begin{array}{l}\text { Cation transmembrane } \\
\text { transporter activity }\end{array}$ & Unknown \\
\hline A116-3* & $\begin{array}{l}\text { L-ascorbate oxidase like protein, } M \text {. } \\
\text { truncatula, XP_00361 1827.1, 4e-05 }\end{array}$ & Ion transport & Copper ion binding & Unknown \\
\hline $\mathrm{A} 121-1^{*}$ & $\begin{array}{l}\text { AT5G57110 (Ca2+ transporting ATPase), } \\
\text { A. thaliana, BAH20100.1, 6e-05 }\end{array}$ & $\begin{array}{l}\text { Calcium transport, ATP } \\
\text { biosynthetic process }\end{array}$ & Calcium ion transport & Membrane \\
\hline A123-1* & $\begin{array}{l}\text { Potassium channel tetramerization } \\
\text { domain-containing protein, } R \text {. } \\
\text { communis, XP_002509821.1, 3e-29 }\end{array}$ & Ion transport & $\begin{array}{l}\text { Voltage-gated potassium } \\
\text { channel activity }\end{array}$ & Membrane \\
\hline A125-1* & F16A14.19, A. thaliana, AAF79412.1, 8e-20 & Transport & Anion channel activity & Unknown \\
\hline$A 118^{* *}$ & $\begin{array}{l}\text { ABC transporter family, M. } \\
\text { truncatula, XP_003590459.1, 8e-27 }\end{array}$ & Unknown & Ttransporter activity & Plasmodesmata \\
\hline \multicolumn{5}{|l|}{ Translation } \\
\hline $\mathrm{A} 22^{*}$ & $\begin{array}{l}40 \text { S ribosomal protein SA, } M \text {. } \\
\text { truncatula, XP_003638087.1, 4e-3 }\end{array}$ & Translation & Ribonucleoprotein & Cytoplasm \\
\hline $\mathrm{A} 73^{* *}$ & $\begin{array}{l}\text { 60S ribosomal protein L27a-3, M. } \\
\text { Truncatula, XP_003613127.1, 2e-16 }\end{array}$ & Translation & $\begin{array}{l}\text { Structural constituent } \\
\text { of ribosome }\end{array}$ & Ribosome \\
\hline AC39GA2* & $\begin{array}{l}\text { Translation initiation factor EIF-2B epsilon, } \\
\text { M. truncatula, XP_003618849.1, 3e-06 }\end{array}$ & Translation & $\begin{array}{l}\text { Translation initiation factor } \\
\text { activity }\end{array}$ & Unknown \\
\hline $\mathrm{AC41GF1**}$ & $\begin{array}{l}60 \text { S ribosomal protein } L 34, M \text {. } \\
\text { truncatula, XP_003621181.1, 6e-09, }\end{array}$ & Translation & Ribnucleoprotein & $\begin{array}{l}\text { Large subunit } \\
\text { of ribosome }\end{array}$ \\
\hline \multicolumn{5}{|c|}{ Transcription regulator } \\
\hline$A C 47 G E 1^{*}$ & SRCI, Glycine max, BAA19768.1, 0.096 & Cold stress regulation & Transcription & Unknown \\
\hline \multicolumn{5}{|c|}{ Carbohydrate metabolism } \\
\hline $\mathrm{A} 36-2^{*}$ & $\begin{array}{l}\text { Beta-galactosidase, Arabidopsis } \\
\text { thaliana, CAB64750.1, 4e-3 }\end{array}$ & $\begin{array}{l}\text { Carbohydrate metabolism, } \\
\text { pollen development }\end{array}$ & $\begin{array}{l}\text { Beta-galactosidase } \\
\text { activity }\end{array}$ & Apoplast \\
\hline A59-2* & $\begin{array}{l}\text { Glycerol kinase, Glycine max, } \\
\text { NP_001237303.1, 1e-21 }\end{array}$ & Glycerolipid metabolism & Glycerol kinase activity & Unknown \\
\hline A $102-2^{*}$ & $\begin{array}{l}\text { Aconitate hydratase, M. truncatula, } \\
\text { XP_003612247.1, 4e-24 }\end{array}$ & $\begin{array}{l}\text { Carbohydrate metabolism } \\
\text { (converts citrate to isocitrate) }\end{array}$ & $\begin{array}{l}\text { Iron sulfur } \\
\text { cluster binding }\end{array}$ & Cytoplasm \\
\hline $\mathrm{AC44GA} 2^{*}$ & $\begin{array}{l}\text { Sucrose phosphorylase, Vibrio } \\
\text { harveyi HY01, ZP 01985256.1, } 0.64\end{array}$ & Starch and sucrose metabolism & $\begin{array}{l}\text { Cation binding, sucrose } \\
\text { phosphorylase activity }\end{array}$ & Unknown \\
\hline \multicolumn{5}{|c|}{ Pollen development } \\
\hline $\mathrm{A} 10^{*}$ & $\begin{array}{l}\text { Peroxisomal ABC transporter, } M \text {. } \\
\text { truncatula, XP_003601968.1, 1e-10 }\end{array}$ & $\begin{array}{l}\text { Transport (fatty acids), Pollen tube } \\
\text { elongation, ovule fertilization, and } \\
\text { seeds germination after imbibition }\end{array}$ & ATP binding & $\begin{array}{l}\text { Glyoxisomal } \\
\text { membrane }\end{array}$ \\
\hline$A 60^{*}$ & $\begin{array}{l}\text { Pectin methylesterase, M. truncatula, } \\
\text { XP_003595372.1, 7e-17, }\end{array}$ & $\begin{array}{l}\text { Cell wall modification, tetrad } \\
\text { separation, pollen tube growth }\end{array}$ & $\begin{array}{l}\text { Pectin methylesterase } \\
\text { activity }\end{array}$ & Membrane \\
\hline A99-1* & $\begin{array}{l}\text { Microspore-specific promoter2, } \\
\text { Arabidopsis thaliana, NP_5686669.1, } 0.02\end{array}$ & Pollen development & Transcription & Chloroplast \\
\hline $\mathrm{A} 101^{*}$ & $\begin{array}{l}\text { Pectin esterase, M. truncatula, } \\
\text { XP_003591164.1, 1e-06 }\end{array}$ & $\begin{array}{l}\text { Cell wall modification, } \\
\text { pollen tube growth }\end{array}$ & $\begin{array}{l}\text { Pectin methylestera } \\
\text { activity }\end{array}$ & Cell wall \\
\hline A104-2* & $\begin{array}{l}\text { SYP124 (SYNTAXIN OF PLANTS); } \\
\text { SNAP receptor. M. truncatula. }\end{array}$ & $\begin{array}{l}\text { Vesicular mediate transport, } \\
\text { intracellular protein transport }\end{array}$ & SNAP receptor activity & Membrane \\
\hline
\end{tabular}


Table 2 Functional characterization of $\mathbf{3 5}$ differentially expressed transcripts from the DDRT-PCR (Continued)

\begin{tabular}{|c|c|c|c|c|}
\hline AC52GD1* & $\begin{array}{l}\text { Protein WAX2, M. truncatula, XP_003606194.1, } \\
\text { 5e-28 }\end{array}$ & Pollen sperm cell differentiation & $\begin{array}{l}\text { Iron ion binding, fatty } \\
\text { acid biosynthetic process }\end{array}$ & $\begin{array}{l}\text { Integral to } \\
\text { membrane }\end{array}$ \\
\hline A64-1** & $\begin{array}{l}\text { Early nodulin-like protein, } M \text {. } \\
\text { truncatula, XP_003609073.1, 8e-04 }\end{array}$ & Pollen development & Copper ion binding & Membrane \\
\hline \multicolumn{5}{|c|}{ Signal transducer activity } \\
\hline $\mathrm{A} 67^{*}$ & $\begin{array}{l}\text { Cysteine-rich receptor-like protein } \\
\text { kinase, M. truncatula, XP_003589476.1, 2e-3 }\end{array}$ & $\begin{array}{l}\text { Calcium-mediated Signal } \\
\text { transduction, pollen development, } \\
\text { recognition of pollen }\end{array}$ & $\begin{array}{l}\text { Protein serine/threonine } \\
\text { kinase activity }\end{array}$ & Membrane \\
\hline $\mathrm{A} 81^{*}$ & $\begin{array}{l}\text { Protein kinase serine/threonine, } \\
\text { A. thaliana, CAA16700.1, 1e-37 }\end{array}$ & Signal transduction & $\begin{array}{l}\text { Protein serine/threonine } \\
\text { kinase activity }\end{array}$ & Nucleus \\
\hline A97-2* & $\begin{array}{l}\text { Ralf-like } 19 \text { protein, , } A \text {. } \\
\text { thaliana, NP_850219.1, 5e-25 }\end{array}$ & Signal transduction & Unknown & Unknown \\
\hline A120-2* & $\begin{array}{l}\text { Serine/threonine protein kinase, } M \text {. } \\
\text { truncatula, XP_003618563.1, 2e-3 }\end{array}$ & Signal transduction & $\begin{array}{l}\text { Protein serine/threonine } \\
\text { kinase Activity }\end{array}$ & Unknown \\
\hline $\begin{array}{l}\text { A140-2* (pollen } \\
\text { development) }\end{array}$ & $\begin{array}{l}\text { Cyclin-dependent kinase CDC2C, M. } \\
\text { truncatula, XP_003621316.1, 2e-36 }\end{array}$ & $\begin{array}{l}\text { Signal transduction, } \\
\text { pollen tube growth }\end{array}$ & $\begin{array}{l}\text { Serine/threonine } \\
\text { protein kinase }\end{array}$ & Unknown \\
\hline AN59CA2* & $\begin{array}{l}\text { Casein kinase, Ricinus communis, } \\
\text { XP_002516524.1, 5e-17 }\end{array}$ & Signaling transduction & ATP binding & Unknown \\
\hline \multicolumn{5}{|l|}{ Defense } \\
\hline A126-1* & $\begin{array}{l}\text { Wound responsive protein, } \\
\text { Phaseolus vulgaris, Q09020.1, 7e-07 }\end{array}$ & Defense & Unknown & Unknown \\
\hline $\mathrm{A} 114^{* *}$ & $\begin{array}{l}\text { RRP1, Medicago truncatula, } \\
\text { AB1511616.1, 0.1e-4 }\end{array}$ & $\begin{array}{l}\text { Defense, resistance to } \\
\text { Peronospora parasitica }\end{array}$ & Unknown & Unknown \\
\hline \multicolumn{5}{|l|}{ Energy } \\
\hline$A C 45 G A 3^{* *}$ & $\begin{array}{l}\text { ATPase subunit 8, Lotus japonicus, } \\
\text { YP_005090498.1, 2e-71 }\end{array}$ & Energy & $\begin{array}{l}\text { Hydrogen ion } \\
\text { transmembrane } \\
\text { transporter activity }\end{array}$ & Mitochondria \\
\hline \multicolumn{5}{|c|}{ Metabolic processes } \\
\hline A98-2* & Hydrolase, Zea mays, NP_001150070.1, 1e-6 & Unknown & Hydrolase activity & Unknown \\
\hline \multicolumn{5}{|l|}{ Cell division } \\
\hline A71-1** & $\begin{array}{l}\text { Cell division cycle and apoptosis } \\
\text { regulator protein, M. truncatula, } \\
\text { XP_003613873.1, 5e-07 }\end{array}$ & Cell division & Unknown & Unknown \\
\hline
\end{tabular}

Homologies are as per BLASTX.

*Up-regulated, **Down-regulated.

and having both the UP (16 nos.) and DR (9 nos.) transcripts was selected for RT-qPCR analysis (Additional file 2). These ESTs, in RT-qPCR, had differential expression similar to DDRT-PCR. In the category of UP genes, three transcripts i.e. AC44GA2 (sucrose phosphorylase, 122.2 fold at $72 \mathrm{~h}$ ), AC39GA2 (translation initiation factor EIF-2B epsilon, 88.3 fold at $24 \mathrm{~h}$ ) and A10 (peroxisomal ABC transporter, 42.7 fold at $120 \mathrm{~h}$ ) showed maximum increase over the untreated control (Figure 4A, Additional file 3). Other highly UP transcripts were A-126 (wound-responsive gene; 12.6 fold at $72 \mathrm{~h}$ ), A59-2 (glycerol kinase; 9.2 fold at $12 \mathrm{~h}$ ), A36-2 (beta-galactosidase; 6.2 fold at $72 \mathrm{~h}$ ), A58 (unknown; 5.4 fold at $12 \mathrm{~h}$ ) and A60 (PME; 4.9 fold at $12 \mathrm{~h}$, Figure 4B). Among DR transcripts, the expression of seven transcripts out of nine declined to zero at different time points after cold stress (Figure 4C). Only one transcript i.e. AC41GF1 (translation) showed quick decline in expression to zero following $1.5 \mathrm{~h}$ of cold stress.
Time point expression also allowed us to identify the time at which the genes showed more than two- fold increase/decrease (Figure 5). The UP genes with more than two fold increase within $1.5 \mathrm{~h}$ were termed as 'early-on' whereas those with such increase at $72 \mathrm{~h}$ or $120 \mathrm{~h}$ were termed as 'late-on'. The genes with more than two fold increase at $12 \mathrm{~h}$ or $24 \mathrm{~h}$ were called 'intermediate'. Eight genes were 'early-on', four 'intermediate' and four 'late-on' (Figure 5A, Additional file 3A, C). The role of some of the transcripts (A20, A108-2, A166-1, A36-2 and A59-2) appeared to be restricted only to early stages of cold tolerance (Additional file 3A) as their expression declined to the levels of non-stressed anthers by 72 or $120 \mathrm{~h}$. Among the DR genes, A71-1 (cell division), A155-1 (energy) and AC41GF1 (translation) were early in down-regulation; A62 (unknown), A95-1 (unknown), A170-1 (unknown) and A118 (transport) were 'intermediate'; and A114 (defense) and A77-2 (unknown) were late in down 


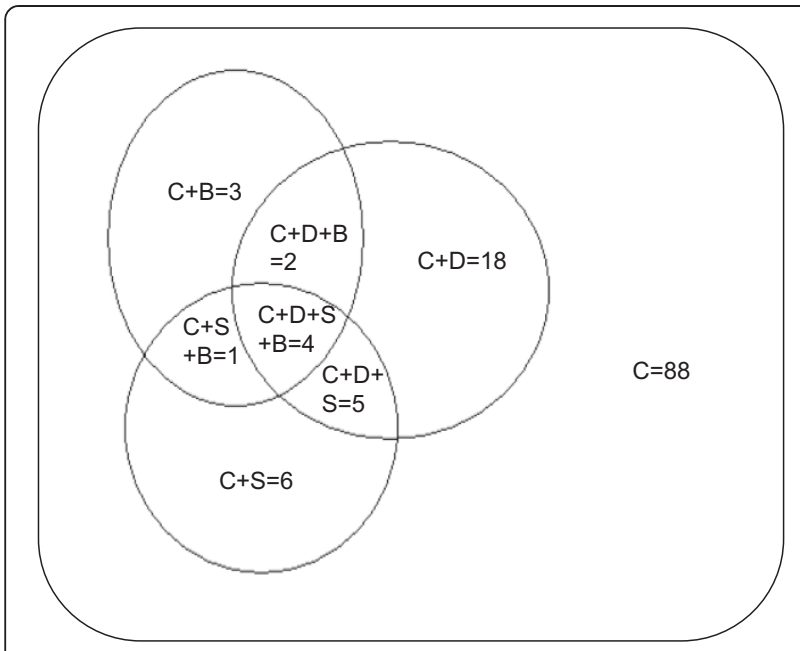

Figure 3 Number of cold-responsive transcripts which are common to other stresses. The stresses were $C$, cold; D, drought; S, salinity; B, biotic stress. The drought, salinity and biotic stress responsive chickpea ESTs in databases that had homology to cold tolerance responsive transcripts (present study) were identified using NCBI-BLASTN. The number of transcripts which were common to at least one stress other than cold was 39.

regulation (Figure 5B, Additional file 3B). Thus, the regulation of expression whether that of UP or DR genes was in a time-limited manner.

\section{Spatial and temporal expression of genes in anthers, gynoecium, leaves and roots}

The expression of the 25 genes, which were used for time point expression studies in anthers, was also elucidated in anthers, gynoecium, leaves and roots (Additional file 4, Figure 6). The aim was to understand gene regulation under cold stress in different chickpea organs and to identify organ specificity in gene expression. The differential gene regulation in different organs at different time points was evident. The expression of five transcripts, A166 (unknown), glycerol kinase (A59-2), PME (A60), translation (A22), and A108-2 (unknown) was significantly higher in anthers compared to other organs indicating their anther-specificity and their important role in anther development under cold. The transcript A166 expressed only in anthers but not in other organs except at $72 \mathrm{~h}$ when it expressed in roots too. Three transcripts i.e. cation efflux protein (A20), A71-2 (unknown) and A58 (unknown) had very high expression in leaves compared to other organs (Additional file 4) whereas peroxisomal $\mathrm{ABC}$ transporter (A10) it did not express in roots at any time point. The transcript A126 was root-specific as it had higher expression in roots compared to other organs.

All anther genes except one i.e. A166 expressed in gynoecium. This pointed towards high degree of commonality in genes involved in cold tolerance in the two reproductive organs i.e. anther and gynoecium. Two of the genes (A36-2, A114) expressed only in anther and gynoecium and not in other organs. The commonality of cold-responsive genes in anthers and gynoecium did not mean similar patterns of gene regulation. Only 9 out of 25 genes have similar patterns of gene regulation between the two organs (Additional file 4). The remaining 16 genes have contrasting patterns of regulation. While the expression of these genes in one of the organs was high, in other, it was low. Among these 16 genes, a group of 6 genes had unique patterns of regulation between the two organs (Figure 6). These genes, in one of the organs, showed increase in expression over time, while in other there was gradual decrease over time. For example, the expression of A36-2 in gynoecium was 3.8 times to that in anthers at $1.5 \mathrm{~h}$, it decreased to 0.6 times at $24 \mathrm{~h}$ and the gene was switched off in gynoecium by $72 \mathrm{~h}$. In contrast to this, the expression in anthers was low at $1.5 \mathrm{~h}$ but it increased steadily over time and reached a peak at $72 \mathrm{~h}$, the time by which it was switched off in gynoecium. The other genes in this group were A140-2, AC47GE1, AC41GF1, A62 and A71-2. All these genes except A62 showed up-regulation over time in anthers and downregulation in gynoecium (Figure 6).

\section{Discussion}

\section{DDRT-PCR identified novel genes for cold tolerance} in anthers

Male gametophyte is the most sensitive chickpea organ to cold stress. Microsporogenesis and subsequent pollen development are affected adversely when chickpea plants are exposed to temperatures below $10^{\circ} \mathrm{C}$ [2]. Cold-hardy chickpea genotypes on the other hand maintain normal anther and pollen development leading to pod formation and seed set [15]. The present study revealed 127 differentially expressed transcripts in tolerant genotype of chickpea under cold stress including 92 (72.4\%) novel ones for which GO descriptions are not available. It appears that induction of cold tolerance in chickpea is regulated by a relatively small number of genes (present study, [22]). Similar to our study, the number of transcripts (1\%; 96 out of 7300) with altered expression was also less in meiotic anthers of heat stressed but heattolerant tomatoes [24]. The comparison between heat tolerant and heat susceptible tomato genotypes vis-à-vis number of differentially expressed genes under heat stress was also made [24]. The number of altered transcripts was almost same in both types of the genotypes but the patterns of gene regulation were different. While majority of the genes were UP in the tolerant genotype of tomato, majority were DR in the susceptible one [24]. Similar pattern of gene regulation was also observed in chickpea anthers (present study) where more than two third (70.9\%) of the altered transcripts were UP as a result of cold stress in the tolerant chickpea genotype. Gene 


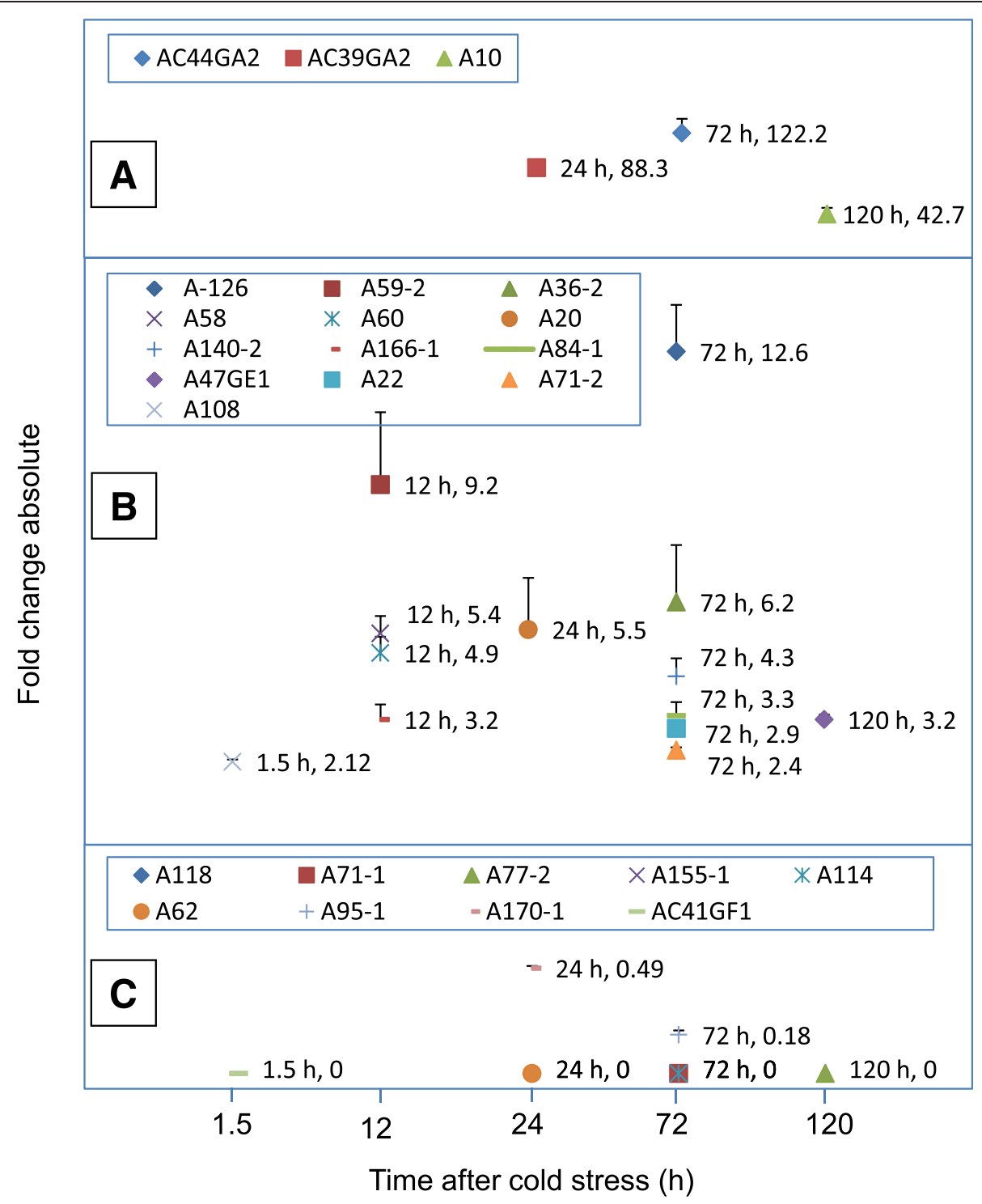

Figure 4 Time after onset of cold stress at which the up-regulated genes showed maximum expression and down-regulated genes the maximum repression. The expression in up-regulated genes decreased after this time point whereas in down-regulated genes it either remained the same or increased. The expression in anthers of ICC16349 was studied using RT-qPCR at six time points ( 0 h, $1.5 \mathrm{~h}, 12 \mathrm{~h}, 24 \mathrm{~h}, 72 \mathrm{~h}$ and $120 \mathrm{~h}$ ) after cold stress and is presented as fold change absolute compared to expression at $0 \mathrm{~h}$. Chickpea actin gene acted as control and was used for normalization of expression data. The functions of the ESTs as per gene ontology are A140-2: signal transduction; AC47GE1: transcription; A36-2, A59-2, AC44GA2: carbohydrate metabolism; A10, A60: pollen development; A20, A118: transport; A114, A126-1: defense; A22, AC39GA2, AC41GF1: translation; A71-1: Cell division; A58, A62, A71-2, A77-2, A84-1, A95-1, A108-2, A155-1, A166, A170-1: unknown function. Panel (A), (B) show up-regulated and panel (C) down-regulated genes, respectively.

regulation under cold stress in tolerant Arabidopsis and susceptible sunflower was also similar to that observed in tomato and chickpea $[25,26]$.

\section{Temporal and spatial gene regulation during cold stress} tolerance

Spatial and temporal control of gene expression is crucial for the development of different plant organs including anthers [27]. The regulation of chickpea anther genes under cold stress was also in a time limited manner. For example, the expression pattern of genes for cell wall, carbohydrate metabolism and fatty acid metabolism matched to the physiological development of pollen during early stages. At the time of onset of cold treatment, the chickpea anthers had microspores in the tetrad stage [present study]. Rapid and highly orchestrated developments leading to mature pollen development take place in anthers after tetrad formation [28]. Some important 


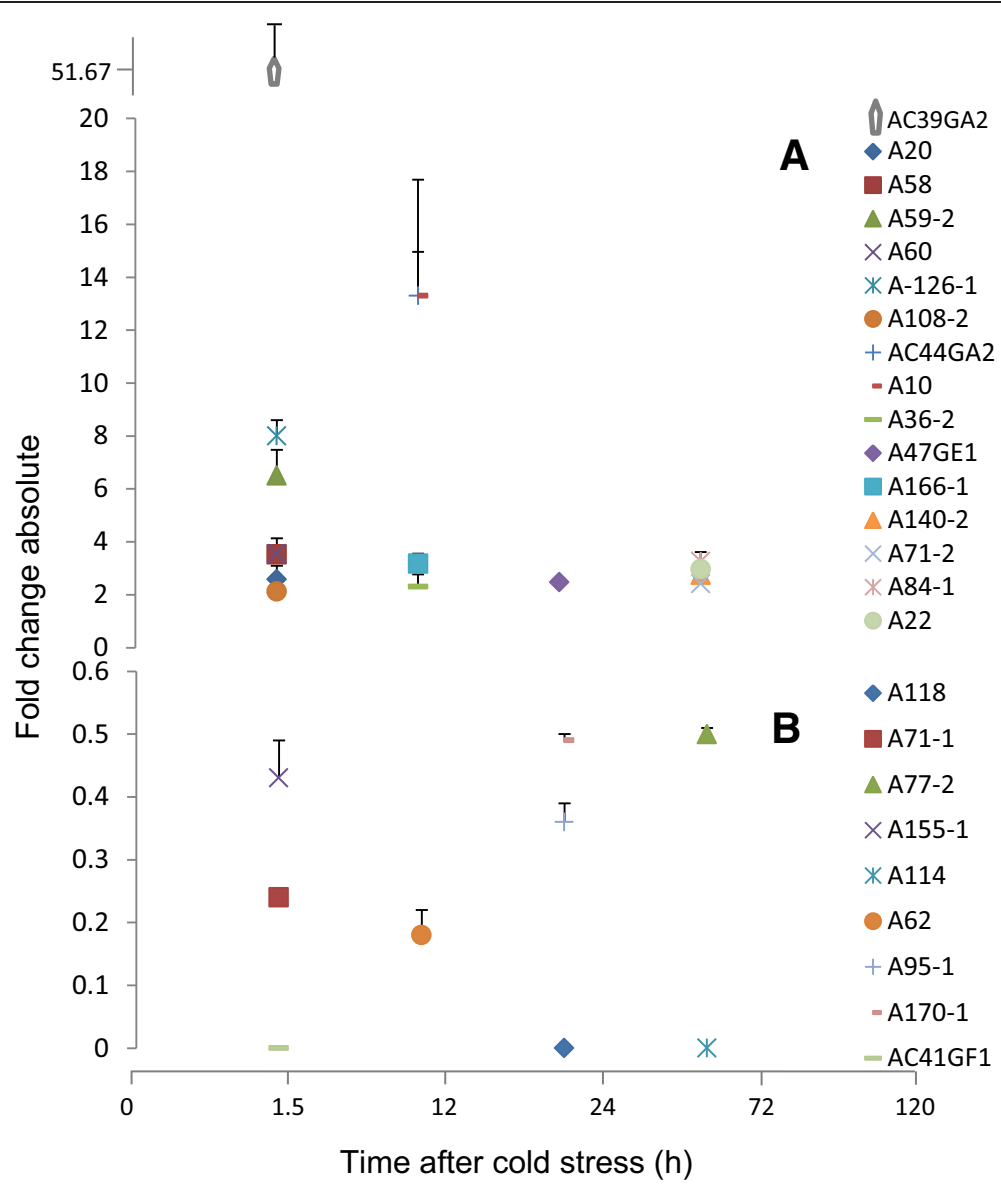

Figure 5 Time after onset of cold stress at which the transcripts showed $>\mathbf{2}$ fold change in expression. The expression using RT-qPCR was studied at six time points ( $0 \mathrm{~h}, 1.5 \mathrm{~h}, 12 \mathrm{~h}, 24 \mathrm{~h}, 72 \mathrm{~h}$ and $120 \mathrm{~h})$ after initiation of cold stress and is presented as fold change absolute compared to expression at $0 \mathrm{~h}$. Chickpea actin gene acted as control and was used for normalization of expression data. The functions of the ESTs as per gene ontology are A140-2: signal transduction; AC47GE1: transcription; A36-2, A59-2, AC44GA2: carbohydrate metabolism; A10, A60: pollen development; A20, A118: transport; A114, A126-1: defense; A22, AC39GA2, AC41GF1: translation; A71-1: Cell division; A58, A62, A71-2, A77-2, A84-1, A95-1, A108-2, A155-1, A166, A170-1: unknown function. Panel (A) shows up-regulated and panel (B) down-regulated genes, respectively.

morphological/physiological features during this phase are separation and expansion of microspores, pollen mitosis I, pollen mitosis II and pollen maturation. During these stages, the tapetum cells feed nutrients to developing microspores [29]. The genes with BP as tetrad separation (PME), pollen expansion by cell wall loosening (beta-galactosidase) and triacylglycerol metabolism leading to sucrose synthesis (glycerol kinase) were up-regulated within $1.5 \mathrm{~h}$ of cold stress. Early expression of these genes matched with the morphological features of pollen development i.e. tetrad separation and microspore expansion. Since, tapetum stores lipids which are utilized by rapidly developing microspores in anthers [30,31], glycerol kinase might be the possible enzyme to convert tapetum lipids to sucrose. The genes, sucrose phosphorylase (BP: production of free sugars from sucrose, KEGG Pathway) and peroxisomal $\mathrm{ABC}$ transporter (BP: pollen maturation, pollen exine formation and male fertility, MF: transportation of fatty acids for $ß$-oxidation, [32,33]) over-expressed later than early UP genes. It might be possible that sucrose produced by the glycerol kinase is the target molecule for sucrose phosphorylase and peroxisomal $\mathrm{ABC}$ transporter supplies necessary triacylglycerols for action by glycerol kinase. The up-regulation of peroxisomal $\mathrm{ABC}$ transporter up to $120 \mathrm{~h}$ indicated its possible role till later stages of pollen development.

\section{Carbohydrate metabolism: an important part of cold tolerance mechanism in chickpea anthers}

The DDRT-PCR, time point and spatial expression data pointed towards the prominent role of carbohydrate metabolism in cold tolerance by anthers of the tolerant chickpea genotype ICC16349. In the present study, all four genes related to carbohydrate metabolism showed over-expression in cold-stressed anthers. Among these genes, the sucrose phosphorylase catabolizes sucrose to yield fructose and glucose (KEGG pathway), the betagalactosidase acts on beta-galactosides and the aconitate 


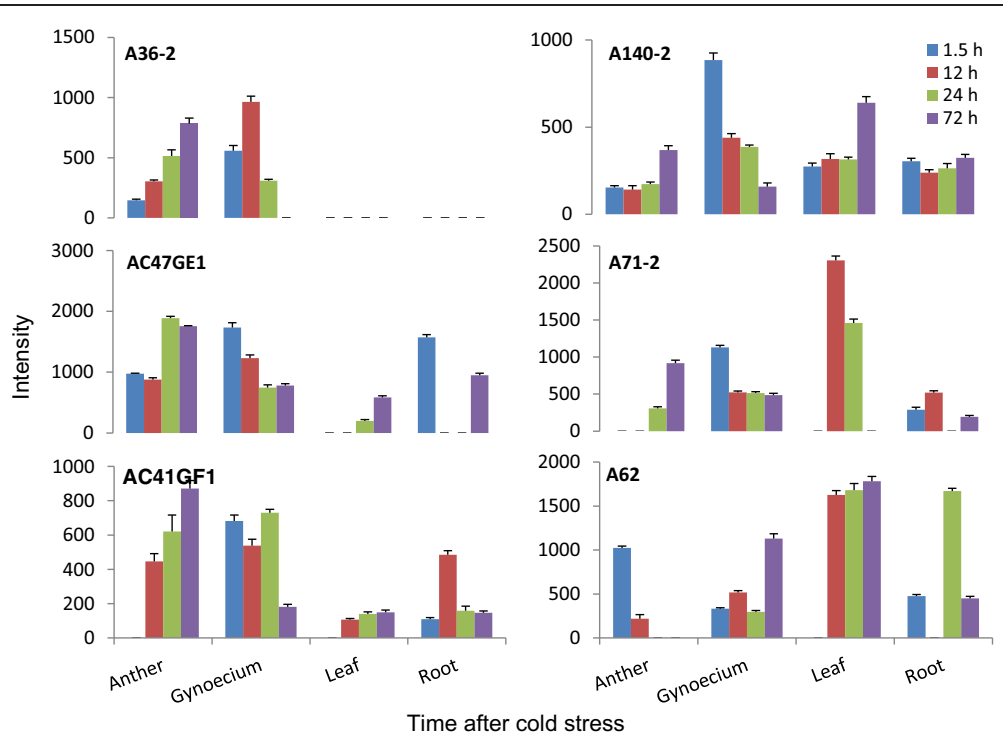

Figure 6 Differential gene expression in cold-stressed anthers and gynoecium of ICC16349. Only those genes with contrasting expression patterns in terms of increase or decrease over time between the two organs are presented. The comparative expression in leaves and roots is also presented. All the four organs were harvested from same set of plants. The expression using RT-qPCR was studied at four time points (1.5 h, $12 \mathrm{~h}, 24 \mathrm{~h}$ and $72 \mathrm{~h}$ ) after cold stress and is presented as intensity of the RT-qPCR bands. Chickpea actin gene acted as control and was used for normalization. The functions of the ESTs as per gene ontology are A140-2: signal transduction; AC47GE1: transcription; A36-2: carbohydrate metabolism; AC41GGF1: translation; A62, A71-2: unknown function.

dehydratase catalyzes conversion of citrate to isocitrate in the tricarboxylic cycle through which energy is generated and precursors for important biomolecules are synthesized (KEGG pathway). The glycerol kinase converts triacylglycerols to sucrose, a substrate for sucrose phosphorylase. A transporter of triacylglycerols (peroxisomal ABC transporter) was also UP. Outcome of overexpression of these genes would be the production of higher amounts of free sugars (sucrose, glucose and fructose) that in plants provide necessary energy and carbon skeleton for growth. Rapid microspore/pollen developments after meiosis also need higher amounts of energy and carbon [1-3]. It appears that the tolerant ICC16349 ensures adequate free sugar accumulation by enhancing the expression of carbohydrate and fatty acid metabolism genes. The free sugars might also serve another purpose as osmolytes and cryoprotectants. Physiological studies in cold-susceptible plants of chickpea have revealed that the disruption of sugar metabolism is the cause of cold induced pollen sterility $[3,13]$. Decreased carbohydrate supply is one of the major factors for coldinduced pollen sterility in susceptible genotypes of several crops including chickpea $[3,13,15,34]$. Cold-treated susceptible plants accumulate low levels of free sugars and flowers of such plants abort [13]. On the other hand, soluble sugars enhance cold stress tolerance in cold-hardy plants [34]. Comparison between cold-susceptible and tolerant plants showed that the leaves of cold-treated tolerant chickpea genotypes had higher amounts of sugars than the treated susceptible ones [15].
Pollen development genes: additional mechanism of viable pollen formation under cold stress?

Accumulation of free sugars in anthers was considered to be the major mechanism for formation of viable anthers/pollen in chickpea as well as other crops $[3,13,15]$. Our study, however, pointed towards the possibility of occurrence of additional mechanisms involving pollendevelopment specific genes. Of the genes with known function, $28.6 \%$ are involved in pollen development and pollen tube growth in other crops (Table 2). It is well established that separation of tetrad during microsporogenesis requires loosening of cell wall. At least three genes with possible role in cell wall loosening and release of pollen grains from tetrad were UP in the present study. These were PME, PE and beta-galactosidase. The PME has been shown to loosen cell walls leading to pollen release [35,36] and in Arabidopsis mutated for this gene, pollen grains were released as tetrad [35]. Similarly, betagalactosidase was associated with pollen expansion after microspore meiosis [37,38]. Microsporogenesis followed by pollen development is a metabolically very active phase in plant reproduction $[2,3]$ and requires continuous supply of wall and other materials. It might be possible that the genes for intracellular protein transport (SYP124, vesicular mediated transport) and fatty acid transport (peroxisomal ABC transporter) UP in the cold-treated anthers, fulfill this requirement. It is already established that the peroxisomal $\mathrm{ABC}$ transporter plays role in pollen maturation, pollen exine formation and pollen tube growth $[32,33]$ 
whereas SYP124 in pollen tube growth [39]. Another gene, WAX2 is required for fertility and seed formation in Arabidopsis [40]. The wax2 mutants suffered from severe pollen sterility and seedlessness, at least under low humidity conditions [40]. ENODL6 is also involved in pollen development [41]. In addition to this, two signal transducers (cysteine rich receptor-like protein kinase and $\mathrm{CDC} 2 \mathrm{C}$ ) with $\mathrm{BP}$ as pollen development (GO description) were also UP. It appears that anther development in coldhardy ICC16349 under cold stress is due to accumulation of free sugars and osmolytes (present study, [15]). On the other hand, the viable pollen development under cold stress might involve both the pollen development and carbohydrate metabolism genes. Further studies are, however, needed to support this hypothesis.

\section{Conclusions}

In this study, a global view of gene expression in anthers of a cold-tolerant genotype during cold stress was obtained. This is the first study on transcriptome of chickpea anthers and it revealed that relatively less number of anther transcripts were altered in cold- tolerant chickpea as a result of cold stress. More than two third of the differentially regulated transcripts were novel with unknown $\mathrm{BP}$ and MF. Another unique feature was up-regulation of majority of the altered transcripts. Pollen development, transport, signal transduction and carbohydrate metabolism were the four important GO subcategories comprising 25 of the 35 functionally characterized transcripts. The expression of altered genes over time in cold stressed anthers revealed that some genes over-expressed immediately after onset of stress while others took several hours or days to do so. Spatio-temporal transcript expression involving four organs and four time points revealed differences in gene regulation in anthers, gynoecium, leaves and roots as a result of cold stress. The patterns of gene regulation in anthers and gynoecium were interesting. Though, all genes except one were common in these two organs, the expression patterns of majority of the genes were contrasting. While the expression in one organ increased with time after cold stress, the expression in other organ decreased. The study pointed towards the existence of dual cold tolerance mechanism operating in tolerant chickpea anthers. While the anthers were protected by enhancing triacylglycerol and carbohydrate metabolism, normal pollen development appeared to be ensured by regulating pollen development and carbohydrate metabolism genes. Chickpea is also affected by abiotic stresses other than cold [42]. In chickpea, there exists a cross talk among genic responses to abiotic (drought, cold, high salinity) and biotic (fungal pathogen Ascochyta rabiei) stresses $[43,44]$. To breed multi-stress tolerant chickpea, there is a need to identify shared as well as unique genes/responses leading to viable pollen development under different abiotic stresses.

\section{Methods}

Plant material, growth conditions and stress treatment Chickpea genotype ICC16349 (cold-tolerant) was grown in the greenhouse at $25 \pm 1^{\circ} \mathrm{C} / 22 \pm 1^{\circ} \mathrm{C}(12 \mathrm{~h}$ day/12 $\mathrm{h}$ night cycles) with approximately $50-70 \%$ relative humidity until flowering. The plants were illuminated $(16 \mathrm{~h} / 8 \mathrm{~h}$ light/dark cycle) using overhead white fluorescent tubes $\left(300 \mu \mathrm{mol} \mathrm{m} \mathrm{m}^{-2} \mathrm{~s}^{-1}\right)$. In each 10" diameter plastic pot filled with soil, sand and vermicompost (1:1:1), two plants were grown. At a fixed time in the day, the flowers at three days pre-pollen dehiscence stage were tagged and the plants were shifted to a cold chamber (Blue Star, $5 \pm 1^{\circ} \mathrm{C}$, humidity $50-60 \%)$ illuminated with overhead white fluorescent tubes ( $16 \mathrm{~h}$ light $/ 8 \mathrm{~h}$ dark cycle). To identify cold tolerance genes, three separate experiments were conducted, i) differential display reverse transcriptase polymerase chain reaction (DDRT-PCR) to identify differentially regulated genes in ICC16349 under cold stress, ii) gene expression in anthers of ICC16349 at different time points using RT-qPCR and iii) temporal and spatial expression of genes in anthers, gynoecium, leaves and roots using RT-qPCR (see Figure 1 for flowchart of experimental procedure). The duration of cold stress for DDRT-PCR experiment was $0 \mathrm{~h}$ and $72 \mathrm{~h}$. For time point expression of genes in anthers, cold stress was provided for $0 \mathrm{~h}$, $1.5 \mathrm{~h}, 12 \mathrm{~h}, 24 \mathrm{~h}, 72 \mathrm{~h}, 96 \mathrm{~h}$ and 120 whereas for the spatio-temporal gene expression studies, the duration of stress was $1.5 \mathrm{~h}, 12 \mathrm{~h}, 24 \mathrm{~h}$ and $72 \mathrm{~h}$. The organs from cold-treated plants were harvested within the cold chambers and stored immediately in liquid nitrogen $\left(-196^{\circ} \mathrm{C}\right)$ until RNA isolation. The plants growing at $25 \pm 1^{\circ} \mathrm{C} / 22 \pm 1^{\circ} \mathrm{C}$ and not subjected to cold stress acted as untreated control.

\section{RNA isolation and first strand CDNA synthesis}

Chickpea organs $(50 \mathrm{mg}$ ) were crushed to powder in liquid nitrogen using pestles and mortars and total RNA was isolated using RNAeasy Plant Mini kit (QIAGEN). Traces of DNA from RNA were removed by on-column DNAse treatment and the RNA was stored at $-80^{\circ} \mathrm{C}$. RNA concentration was estimated spectrophotometrically and RNA gel was also run from each batch of RNA to check the quality and verify the concentration. Reverse transcription was carried out (reaction volume $20 \mu \mathrm{l}$ ) using Omniscript RT kit (QIAGEN) as per the manufacturer's instructions except for the quantity of RNA used. While the manufacturer's recommended the use of 50 - 200 ng RNA per reverse transcription reaction (RT), the use of $50 \mathrm{ng}$ RNA per RT yielded only about 20 bands per lane in the DDRT-PCR. The ideal number of bands per lane in DDRT-PCR should be about 50-60. 
Lowering the RNA concentration to $20 \mathrm{ng}$ per RT yielded 50-60 bands per lane (data not shown). In all our experiments, 20 ng RNA per RT was used. The mRNA was reverse transcribed to first strand of cDNA using three independent reactions with three anchored poly $\mathrm{T}$ primers (AAGCTTTTTTTTTTTTTC, AAGCTTTTTTTTTTT TTG, AAGCTTTTTTTTTTTTTA).

\section{DDRT-PCR, electrophoresis and intensity analysis}

Synthesis of the second strand and PCR was carried out in a volume of $25.0 \mu \mathrm{l}$ using cDNA from 2 ng RNA [ $2 \mu \mathrm{l}$ RT solution, $2.5 \mathrm{mM} \mathrm{MgSO} 4,0.1 \mathrm{mM}$ of each dNTP's mix, $0.8 \mu \mathrm{M}$ of anchored and arbitrary primers (Sigma Aldrich, USA) and $1 \mathrm{U}$ of Taq DNA polymerase (Life Tech)]. DDRT-PCR of treated and control anthers was carried out using 240 primer combinations (three anchored vs. 80 arbitrary primers, see Additional file 5 for list of primers) [45]. Amplifications were carried out in a Perkin Elmer Thermal Cycler (Gene Amp PCR System 9700) using 1 cycle of $4 \mathrm{~min}$ at $94^{\circ} \mathrm{C}$ followed by 39 cycles of $15 \mathrm{sec}$ at $94^{\circ} \mathrm{C}$ (denaturation), $2 \mathrm{~min}$ at $40^{\circ} \mathrm{C}$ (primer annealing) and a $30 \mathrm{sec}$ extension at $72^{\circ} \mathrm{C}$ followed by a cycle of $72^{\circ} \mathrm{C}$ for 8 min using the procedure as outlined by Liang et al. [46] with slight modifications. While Liang et al. [46] used fluorescence or radioactive labeling, we used silver staining.

The DDRT-PCR products were resolved on polyacrylamide gels (6\%) and stained with silver nitrate as per Sambrook and Russell [47]. The gels were dried overnight at room temperature and scanned using hp scanjet 8200 scanner (HP) attached to a computer (Sony Vaio). The gel pictures were converted to TIFF files and differentially expressed bands were subjected to intensity analysis using Quantity one software (BioRad).

\section{Recovery, cloning and sequencing of differentially expressed CDNAs}

For isolation of differentially expressed cDNAs, each band was eluted and re-amplified using the primers that were used to amplify the band in DDRT-PCR. The PCR conditions were the same as DDRT-PCR. Re-amplified products were separated on agarose gels (1.4\%), extracted using QAIquick gel elution kit (QIAGEN) and cloned in pGEMT-Easy vector (Promega). The transformed vector was inserted into Escherichia coli strain DH5a. Ampicillin resistant clones were checked for insert and positive clones were sequenced.

\section{Sequence processing, gene annotation and functional categories}

The EST sequences were checked for quality and analyzed by Seqman ${ }^{\text {tw }}$ II 5.08 (DNASTAR, Inc. Lasergene Gene Corporation, Ann Arbor, MI) and VecScreen (http://www.ncbi. nlm.nih.gov/VecScreen/VecScreen.html) to detect and remove pGEMT-Easy vector sequences. Manual sequence processing was also performed to confirm results. EST sequences, which were less than $75 \mathrm{bp}$ long were removed. Duplicate entries were identified using DNASTAR, NCBI-BLAST (http://blast.ncbi.nlm.nih.gov/Blast.cgi) and manually. ESTs were assembled into contigs using default parameters of CAP3 [48]. Gene annotation for identification and putative function was performed using NCBI-BLAST (http://blast.ncbi.nlm.nih.gov/Blast.cgi). The $\mathrm{CC}, \mathrm{BP}$ and MF of genes was determined by performing functional classification according to gene ontology (http:// www.geneontology.org/), UniProt Knowledge base (http:// www.uniprot.org/) and KEGG: Kyoto Encyclopedia of Genes and Genomes (http://www.kegg.jp) after filtering the genes for more than two fold change and $\leq 0.05 \mathrm{P}$-value.

\section{RT-qPCR confirmation of candidate genes related to cold tolerance in anthers}

Twenty five genes with different functions were selected to confirm their expression levels in anthers and spatiotemporal expression in anthers, gynoecium, leaves and roots using RT-qPCR. For RT-qPCR, gene-specific primers (Additional file 2) were designed from cDNA sequences using primer3Plus software (http://www.bioinformatics.nl/ cgi-bin/primer3plus/primer3plus.cgi). RNA for different experiments was isolated from untreated and cold treated organs at different time points as mentioned in the preceding section. First cDNA strand synthesis was carried out as outlined above. The cDNA synthesized using three anchored poly A primers (Additional file 5) was pooled in equal amounts and one $\mu$ l of first strand cDNA mixture (1 ng RNA) was used for $12.5 \mu \mathrm{l}$ RT-qPCR mixture. PCR was conducted in a thermal cycler (BioRad) at the following conditions: $5 \mathrm{~min}$ at $94^{\circ} \mathrm{C}$ followed by 30 cycles at $30 \mathrm{sec}$ at $94^{\circ} \mathrm{C}, 30 \mathrm{sec}$ at $52^{\circ} \mathrm{C}$ and $60 \mathrm{sec}$ at $72^{\circ} \mathrm{C}$ and a final extension step of $72^{\circ} \mathrm{C}$ for $2 \mathrm{~min}$. For normalization of RT-qPCR, Actin $\beta$ gene from chickpea (ACT1, EMBL-ACD37723.1) was used as reference. The PCR products were resolved in $1.4 \%$ agarose gel in tris acetate buffer at $120 \mathrm{v}$ for $1 \mathrm{~h}$ and were visualized using GelRed $^{\mathrm{Tm}}$ Nucleic acid gel stain (Biotium, USA, $1 \mu \mathrm{l}$ of $3 \mathrm{x}$ was added directly to the $12.5 \mu \mathrm{l}$ PCR amplified mix) or ethidium bromide (Amresco, added to the gel @ $1 \mu \mathrm{l}$ per $100 \mathrm{ml}$ gel) in a UV transilluminator (Biorad).

\section{Data normalization and statistical analysis}

After RT, initial concentration of the total cDNA in all the samples used for DDRT-PCR and RT-qPCR was normalized using the chickpea Actin $\beta$ gene. The CT value used was 30 . The expression data (DDRT-PCR as well as RT-qPCR) were normalized to that of reference gene and normalized values were used to calculate fold change. All experiments were performed in two biological 
replicates and three technical replicates. Data were analyzed and graphs drafted using Microsoft Excel 3 (Microsoft, Redmond, USA). The means were expressed as arithmetic mean \pm S.D.

\section{Accession numbers}

The sequences of the transcripts are available under the accession numbers GenBank: JK998687 to JK998825.

\section{Additional files}

\section{Additional file 1: Identification and functional annotation of cold} stress responsive anther transcripts.

Additional file 2: List of transcripts assessed by RT-qPCR and primer sequences.

Additional file 3: Regulation of cold stress responsive genes in anthers of ICC16349 at different time points.

Additional file 4: Spatial and temporal expression of cold stress responsive transcripts in anthers, gynoecium, leaves and roots of a tolerant chickpea line ICC16349.

Additional file 5: The sequences of forward and reverse primers used for DDRT PCR.

\section{Competing interests}

The authors declare that they have no competing interests.

\section{Authors' contributions}

$\mathrm{KD}$ carried out the cold treatments, molecular biology studies, sequence alignment, functional annotation and analyzed the data. KD and HN conceived the study and drafted the manuscript. Both authors read and approved the final manuscript.

\section{Acknowledgements}

The financial assistance (F.No. BT/PR9708/AGR/02/486/2007) from the Department of Biotechnology, Government of India is gratefully acknowledged.

\section{Author details}

'Department of Agricultural Biotechnology, CSK HP Agricultural University, Palampur 176062, HP, India. '2Department of Botany, Panjab University, Chandigarh, India.

Received: 21 December 2013 Accepted: 2 October 2014

Published: 11 October 2014

\section{References}

1. Castro AJ, Clément C: Sucrose and starch catabolism in the anther of Lilium during its development: a comparative study among the anther wall, locular fluid and microspore/pollen fractions. Planta 2007, 225:1573-1582.

2. Thakur P, Kumar S, Malik JA, Berger JD, Nayyar H: Cold stress effects on reproductive development in grain crops: an overview. Env Exp Bot 2010, 67:429-443.

3. Zinn KE, Tunc-Ozdemir M, Harper JF: Temperature stress and plant sexual reproduction: uncovering the weakest links. J Exp Bot 2010, 61:1959-1968.

4. Boyer JS, McLaughlin JE: Functional reversion to identify controlling genes in multigenic responses: analysis of floral abortion. J Exp Bot 2007, 58:267-277.

5. Peet MM, Sato S, Gardner RG: Comparing heat stress effects on male-fertile and male-sterile tomatoes. Plant Cell Environ 1998, 21:225-231.

6. Clément $C$, Laporte $P$, Audran JC: The loculus content and tapetum during pollen development in Lilium. Sex Plant Reprod 1998, 11:94-106.

7. Clément C, Chavant L, Burrus M, Audran JC: Anther starch variations in Lilium during pollen development. Sex Plant Reprod 1994, 7:347-356.

8. Oliver SN, Van Dongen JT, Alfred SC, Mamun EA, Zhao X, Saini HS, Fernandes SF, Blanchard CL, Sutton BG, Geigenberger P, Dennis ES, Dolferus R: Cold-induced repression of the rice anther-specific cell wall invertase gene OSINV4 is correlated with sucrose accumulation and pollen sterility. Plant Cell Environ 2005, 28:1534-1551.

9. Srinivasan A, Saxena NP, Johansen C: Cold tolerance during early reproductive growth of chickpea (Cicer arietinum L.), genetic variation in gamete development and function. Field Crops Res 1999, 60:209-222.

10. Zonia L: Spatial and temporal integration of signalling networks regulating pollen tube growth. J Exp Bot 2010, 61:1939-1957.

11. Singh KB, Malhotra RS, Saxena MC: Relationship between cold severity and yield loss in chickpea (Cicer arietinum L.). J Agron Crop Sci 1993, 170:121-127.

12. Clarke HJ, Siddique KHM: Response of chickpea genotypes to low temperature stress during reproductive development. Field Crops Res 2004, 90:323-334.

13. Nayyar $\mathrm{H}$, Bains $\mathrm{T}$, Kumar $\mathrm{S}$ : Low temperature induced floral abortion in chickpea: relationship to abscisic acid and cryoprotectants in reproductive organs. Env Exp Bot 2005, 53:39-47.

14. Nayyar H, Bains TS, Kumar S, Kaur G: Chilling effect during seed filling on accumulation of seed reserves and yield of chickpea. J Sci Food Agric 2005, 85:1925-1930.

15. Kumar S, Malik J, Thakur P, Kaistha S, Sharma KD, Upadhyaya HD, Berger JD, Nayyar $\mathrm{H}$ : Growth and metabolic responses of contrasting chickpea (Cicer arietinum L.) genotypes to chilling stress at reproductive phase. Acta Physiol Plant 2011, 33:779-787.

16. Kaur G, Kumar S, Thakur P, Malik JA, Bhandhari K, Sharma KD, Nayyar H: Involvement of proline in response of chickpea (Cicer arietinum L.) to chilling stress at reproductive stage. Sci Hortic 2011, 128:174-181.

17. Kumar S, Nayyar H, Bhanwara RK, Upadhyaya HD: Chilling stress effects on reproductive biology of chickpea. SAT eJournal 2010, 8.

18. Varshney RK, Hiremath PJ, Lekha P, Kashiwagi J, Balaji J, Deokar AA, Vadez V, Xiao Y, Srinivasan R, Gaur PM, Siddique KHM, Town CD, Hoisington DA: A comprehensive resource of drought- and salinity responsive ESTs for gene discovery and marker development in chickpea (Cicer arietinum L.). BMC Genomics 2009, 10:523.

19. Molina C, Rotter B, Horres R, Udupa SM, Besser B, Bellarmino L, Baum M, Matsumura H, Ryohei Terauchi R, Günter Kahl G, Winter P: SuperSAGE: the drought stress-responsive transcriptome of chickpea roots. BMC Genomics 2008, 9:553.

20. Deokar AA, Kondawar V, Jain PK, Karuppayil SM, Raju NL, Vadez V, Varshney RK, Srinivasan R: Comparative analysis of expressed sequence tags (ESTs) between drought-tolerant and -susceptible genotypes of chickpea under terminal drought stress. BMC Plant Biol 2011, 11:70.

21. Jaiswal P, Cheruku JR, Kumar K, Yadav S, Singh A, Kumari P, Dube SC, Upadhyaya KC, Verma PK: Differential transcript accumulation in chickpea during early phases of compatible interaction with a necrotrophic fungus Ascochyta rabiei. Mol Biol Rep 2012, 39:4635-4646.

22. Dinari A, Niazi A, Afsharifar AR, Ramezani A: Identification of upregulated genes under cold stress in cold-tolerant chickpea using the CDNA-AFLP approach. PLoS One 2013, 8(1):e52757.

23. Mantri NL, Ford R, Coram TE, Pang ECK: Transcriptional profiling of chickpea genes differentially regulated in response to high-salinity, cold and drought. BMC Genomics 2007, 8:303.

24. Bita CE, Zenoni S, Vriezen WH, Mariani C, Pezzotti M, Gerats T: Temperature stress differentially modulates transcription in meiotic anthers of heat-tolerant and heat-sensitive tomato plants. BMC Genomics 2011, 12:384.

25. Fowler $\mathrm{S}$, Thomashow MF: Arabidopsis transcriptome profiling indicates that multiple regulatory pathways are activated during cold acclimation in addition to the CBF cold response pathway. Plant Cell 2002, 14:1675-1690.

26. Hewezi T, Leger M, Kayal WE, Gentzbitte L: Transcriptional profiling of sunflower plants growing under low temperatures reveals an extensive down-regulation of gene expression associated with chilling sensitivity. J Exp Bot 2006, 57:3109-3122.

27. Wellmer F, Riechmann JL, Alves-Ferreira M, Meyerowitz EM: Genome-wide analysis of spatial gene expression in arabidopsis flowers. Plant Cell 2004, 16:1314-1326

28. Borg M, Brownfield L, Twell D: Male gametophyte development: A molecular perspective. J Exp Bot 2009, 60:1465-1478.

29. Goldberg RB, Beals TP, Sanders PM: Anther development: Basic principles and practical application. Plant Cell 1993, 5:1217-1229.

30. Footitt S, Cornah JE, Pracharoenwattana I, Bryce JH, Smith SM: The Arabidopsis 3-ketoacyl-CoA thiolase-2 (kat2-1) mutant exhibits increased flowering but reduced reproductive success. J Exp Bot 2007, 58:2959-2968. 
31. Watanabe M: Towards a comprehensive understanding of molecular mechanisms of sexual reproduction in higher plants. Plant Cell Physiol 2008, 49:1404-1406.

32. Kuromori T, Ito T, Sugimoto E, Shinozaki K: Arabidopsis mutant of AtABCG26, an $A B C$ transporter gene, is defective in pollen maturation. J Plant Physiol 2011, 168:2001-2005.

33. Quilichini TD, Friedmann MC, Samuels AL, Douglas CJ: ATP-binding cassette transporter $\mathrm{g} 26$ is required for male fertility and pollen exine formation in Arabidopsis. Plant Physiol 2010, 154:678-690.

34. Strand $\AA$, Foyer $\mathrm{CH}$, Gustafsson P, Gardeström P, Hurry V: Altering flux through the sucrose biosynthesis pathway in transgenic Arabidopsis thaliana modifies photosynthetic acclimation at low temperatures and the development of freezing tolerance. Plant Cell Environ 2003, 26:523-535.

35. Francis KE, Lam SY, Copenhave GP: Separation of Arabidopsis pollen tetrads is regulated by QUARTET1, a pectin methylesterase gene. Plant Physiol 2006, 142:1004-1013.

36. Ogawa M, Kay P, Wilson S, Swain SM: Arabidopsis dehiscence zone polygalacturonase1 (ADPG1), ADPG2, and QUARTET2 are polygalacturonases required for cell separation during reproductive development in Arabidopsis. Plant Cell 2009, 21:216-233.

37. Hruba P, Honys D, Twell D, Capkova V, Tupy J: Expression of $\beta$-galactosidase and $\beta$-xylosidase genes during microspore and pollen development. Planta 2005, 220:931-940.

38. Wilson ZA, Song J, Taylor B, Yang C: The final split: the regulation of anther dehiscence. J Exp Bot 2011, 62:1633-1649.

39. UI-Rehman R, Silva PA, Malho R: Localization of arabidopsis SYP125 syntaxin in the plasma membrane sub-apical and distal zones of growing pollen tubes. Plant Signal Behav 2011, 6:665-670.

40. Chen X, Goodwin SM, Boroff VL, Liu X, Jenks MA: Cloning and characterization of the WAX2 gene of Arabidopsis involved in cuticle membrane and wax production. Plant Cell 2003, 15:1170-1185.

41. Mashiguchi K, Asami T, Suzuki Y: Genome-wide identification, structure and expression studies, and mutant collection of 22 early nodulin-like protein genes in Arabidopsis. Biosci Biotechnol Biochem 2009, 73:2452-2459.

42. Ryan J: A Global Perspective on Pigeon Pea and Chickpea Sustainable Production Systems: Present Status and Future Potential. In Recent Advances in Pulses Research. Edited by Asthana A, Ali M. Kanpur: Indian Society for Pulses Research and Development India; 1997:1-31.

43. Mantri NL, Ford R, Coram TE, Pang ECK: Evidence of unique and shared responses to major biotic and abiotic stresses in chickpea. Env Exp Bot 2010, 69:286-292.

44. Mantri NL, Patade V, Penna S, Ford R, Pang E: Abiotic Stress Responses in Plants - Present and Future. In Abiotic Stress Responses in Plants: Metabolism to Productivity. Edited by Parvaiz A, Prasad MNV. New York: Springer; 2012:1-20.

45. Yang $X$, Scheffler $B E$, Weston $L A$ : Recent developments in primer design for DNA polymorphism and mRNA profiling in higher plants. Plant Methods 2006, 2:4.

46. Liang P, Meade JD, Pardee AB: A protocol for differential display of mRNA expression using either fluorescent or radioactive labeling. Nat Protoc 2007, 2:457-470.

47. Sambrook J, Russell DW: Molecular Cloning: A Laboratory Manual, Volume 2. Cold Spring Harbor: Cold Spring Harbor Laboratory Press, New York; 2001.

48. Huang X, Madan A: CAP3: A DNA sequence assembly program. Genome Res 1999, 9:868-877.

Cite this article as: Sharma and Nayyar: Cold stress alters transcription in meiotic anthers of cold tolerant chickpea (Cicer arietinum L.). BMC Research Notes 2014 7:717.

\section{Submit your next manuscript to BioMed Central and take full advantage of:}

- Convenient online submission

- Thorough peer review

- No space constraints or color figure charges

- Immediate publication on acceptance

- Inclusion in PubMed, CAS, Scopus and Google Scholar

- Research which is freely available for redistribution

Submit your manuscript at www.biomedcentral.com/submit 